\title{
Functional Traits of a Rainforest Vascular Epiphyte Community: Trait Covariation and Indications for Host Specificity
}

\author{
Katrin Wagner ${ }^{1}$, Wolfgang Wanek ${ }^{2}$ (D) and Gerhard Zotz ${ }^{1,3, *(D)}$ \\ 1 Institute for Biology and Environmental Sciences, Functional Ecology, Carl von Ossietzky University \\ Oldenburg, Box 2503, D-26111 Oldenburg, Germany; katrin.wagner@uol.de \\ 2 Department of Microbiology and Ecosystem Science, Center of Microbiology and Environmental Systems \\ Science, University of Vienna, A-1090 Vienna, Austria; wolfgang.wanek@univie.ac.at \\ 3 Smithsonian Tropical Research Institute, Balboa, Ancon, Panama City 0843-03092, Panama \\ * Correspondence: gerhard.zotz@uol.de; Tel.: +49-(0)441-798-3315; Fax: +49-(0)441-798-3331
}

Citation: Wagner, K.; Wanek, W.;

Zotz, G. Functional Traits of a Rainforest Vascular Epiphyte Community: Trait Covariation and Indications for Host Specificity. Diversity 2021, 13, 97. https:// doi.org/10.3390/d13020097

Academic Editor: Mario A. Pagnotta

Received: 4 February 2021

Accepted: 18 February 2021

Published: 23 February 2021

Publisher's Note: MDPI stays neutral with regard to jurisdictional claims in published maps and institutional affiliations.

Copyright: (C) 2021 by the authors Licensee MDPI, Basel, Switzerland. This article is an open access article distributed under the terms and conditions of the Creative Commons Attribution (CC BY) license (https:/ / creativecommons.org/licenses/by/ $4.0 /)$.

\begin{abstract}
Trait matching between interacting species may foster diversity. Thus, high epiphyte diversity in tropical forests may be partly due to the high diversity of trees and some degree of host specificity. However, possible trait matching between epiphyte and host is basically unexplored. Since the epiphytic habitat poses particular challenges to plants, their trait correlations should differ from terrestrial plants, but to what extent is unclear as epiphytes are underrepresented or missing in the large trait databases. We quantified 28 traits of 99 species of vascular epiphytes in a lowland forest in Panama that were related to plant size, leaf, stem, and root morphology; photosynthetic mode; and nutrient concentrations. We analyzed trait covariation, community weighted means, and functional diversity for assemblages on stems and in crowns of four tree species. We found intriguing differences between epiphytes and terrestrial plants regarding trait covariation in trait relations between plant maximal height, stem specific density, specific root length, and root tissue den-sity, i.e., stem and root economic spectra. Regarding host specificity, we found strong evidence for environmental filtering of epiphyte traits, but only in tree crowns. On stems, community weighted means differed in only one case, whereas $>2 / 3$ of all traits differed in tree crowns. Although we were only partly able to interpret these differences in the light of tree trait differences, these findings mark an important step towards a functional understanding of epiphyte host specificity.
\end{abstract}

Keywords: host preference; leaf carbon isotope ratio; leaf dry matter content; leaf thickness; leaf nitrogen concentration; leaf nitrogen isotope ratio; root tissue density; root nutrient concentration; specific leaf area; specific root length

\section{Introduction}

Vascular epiphytes (i.e., non-parasitic tracheophytes that spend their entire life on other plants without soil contact) attain high $\alpha$-diversity in many tropical forests [1]. The mechanisms behind local coexistence of such a large number of epiphyte species are poorly understood, although there seems to be a high degree of ecological equivalence among epiphytes so that stochastic processes play an important role in shaping the structure of epiphyte assemblages [2]. However, niche-based processes are also relevant as shown by predictable distribution patterns, such as the separation of species along vertical microclimatic gradients in forest stands [3-5] and an increase in plants with crassulacean acid metabolism (CAM) from wetter to drier forests [6]. Competition, however, does apparently not play an important role as it does in terrestrial systems [1]. Host tree specificity represents another possibility for niche separation [7]. Many studies have aimed at demonstrating distributional biases among tree species [8-10] but their existence and importance have remained elusive. Detecting possible host specificity is hampered by the high species diversity in tropical forests and the associated difficulty to attain adequate sample sizes of tree and epiphyte species in field studies. 
Any kind of specificity among species must entail some degree of "trait-matching" [11] -in the case of host tree specificity a matching between tree and epiphyte traits. A large number of species-specific tree traits may affect the general growing conditions for epiphytes and thus cause host specificity, for example, bark water-holding capacity [12,13], bark stability [12], or crown density [14,15], although their (relative) importance is still basically unclear [7]. Host specificity caused by species-specific differences in tree traits may leave an imprint on the average trait values of epiphyte assemblages. For example, the relative proportion of epiphytes with succulent leaves should be higher in tree species with open crowns, or epiphytes with more adhesive diaspores may be relatively more abundant on trees with smooth bark. There are many species-specific tree traits that may influence epiphyte performance [7]. For example, water availability is contingent on bark roughness and texture (bark water holding capacity), branching architecture (funneling of stemflow), and crown density (throughfall interception). Crown density also influences light interception and vapor pressure deficits (VPD) in the canopy-with stronger seasonal variation in deciduous trees [16]. Bark roughness and stability influence the attachment of epiphyte diaspores. Bark stability, branch turnover, and tree longevity may be effective filters for epiphyte species with a slow life cycle [17]. Nutrient availability may be influenced by leaf and bark nutrient concentrations and their aptitude for leaching [18,19]. Finally, leaf and bark chemistry could also be allelopathic or affect substrate acidity. The large number of candidate traits that can influence growth conditions of epiphytes and their potential covariation arguably makes a mechanistic understanding of host biases difficult. However, systematically varying growth conditions on different tree species should leave detectable imprints on average trait attributes of their epiphyte assemblages due to acclimation of individuals, filtering of genotypes within populations, and species sorting. Detecting correlations between tree and epiphyte characteristics at the species level would provide an unequivocal demonstration of epiphyte host tree specificity.

Currently, plant trait research is a very active field [20]. Most studies focus on soilrooted plants, but there is a recent surge of studies that quantify functional response traits (i.e., traits whose attributes depend on environmental conditions) [21] of vascular epiphytes, addressing changes in functional response traits in relation to elevation [22,23], precipitation $[24,25]$, forest management or forest type [26,27], and height above ground $[3,24]$. However, with the exception of one study [16], host tree specificity has so far not been addressed with a trait-based approach. Moreover, the application of this approach for vascular epiphytes still lags behind the developments of general plant functional trait research with an almost exclusive focus on leaf traits (but see Schellenberger Costa et al. [22], who also quantified plant height and stem specific density, and Einzmann, Schickenberg, and Zotz [24], who focused on anatomical root traits.).

The present study addresses the question of epiphyte host specificity with a trait-based approach. To this end, we studied 28 epiphyte traits in a lowland forest in Panama. Traits included plant size, morphological leaf, stem and root traits, photosynthetic mode, leaf isotope ratios and chlorophyll concentration, and leaf and root nutrient concentrations (Table 1). For many of them, trait-environment relationships have been established for soil-rooted plants. For example, increasing water availability should correlate with lower leaf thickness [28,29], higher specific leaf area and larger leaves [30-32]. We expect similar relationships for epiphytes over the short microclimatic and resource gradients that occur within forest stands-with the caveat that most of the reported trait-environment relationships were observed over much larger environmental gradients. An overview of these expectations is given in Figure 1. 


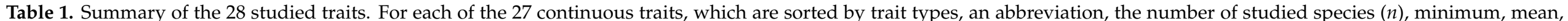

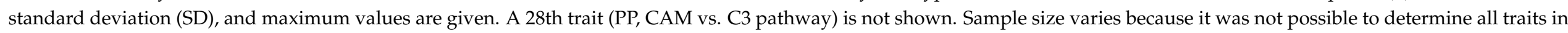

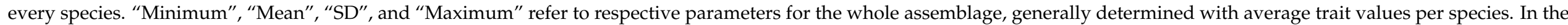
case of plant height and leaf area, the species values $\left(\mathrm{H}_{\max }, \mathrm{LA}_{\max }\right)$ are the largest values observed in a given species.

\begin{tabular}{|c|c|c|c|c|c|c|c|c|}
\hline Trait Type & Abbreviation & Trait & Unit & $n$ & Minimum & Mean & SD & Maximum \\
\hline \multirow[t]{4}{*}{ whole plant } & $\mathrm{H}_{\max }$ & maximum plant height & $\mathrm{cm}$ & 89 & 1 & 46 & 39 & 230 \\
\hline & $\mathrm{L}_{\mathrm{th}}$ & leaf thickness & $\mathrm{mm}$ & 99 & 0.05 & 0.69 & 0.67 & 4.04 \\
\hline & SLA & specific leaf area & $\mathrm{mm}^{2} \mathrm{mg}^{-1}$ & 99 & 2.8 & 18.4 & 13.5 & 66.9 \\
\hline & LDMC & leaf dry matter content & $\mathrm{g} \mathrm{g}^{-1}$ & 99 & 0.03 & 0.18 & 0.10 & 0.59 \\
\hline \multirow[t]{4}{*}{ leaf morphological } & $\mathrm{LA}_{\max }$ & maximum leaf area & $\mathrm{cm}^{2}$ & 94 & 0.1 & 223.6 & 805.7 & 6534.1 \\
\hline & SD & stomatal density & $\mathrm{mm}^{-2}$ & 88 & 12 & 52 & 36 & 193 \\
\hline & SL & stomatal guard cell length & um & 88 & 19 & 38 & 12 & 76 \\
\hline & PSCA & percent stomatal complex area & $\%$ & 88 & 1.0 & 3.8 & 1.8 & 8.6 \\
\hline \multirow[t]{2}{*}{ root morphological } & SRL & specific root length & $\mathrm{m} \mathrm{g}^{-1}$ & 92 & 0.5 & 18.2 & 27.2 & 193.3 \\
\hline & RTD & root tissue density & $\mathrm{g} \mathrm{cm}^{-3}$ & 92 & 0.05 & 0.22 & 0.14 & 0.75 \\
\hline \multirow{6}{*}{$\begin{array}{l}\text { stem morphological } \\
\text { isotope ratios }\end{array}$} & SSD & stem specific density & $\mathrm{mg} \mathrm{mm} \mathrm{m}^{-3}$ & 87 & 0.05 & 0.22 & 0.12 & 0.63 \\
\hline & $\delta^{13} \mathrm{C}$ & leaf carbon isotope ratio & $\%$ & 95 & -36 & -28 & 6 & -12 \\
\hline & $\delta^{15} \mathrm{~N}$ & leaf nitrogen isotope ratio & $\%$ & 95 & -5 & -2 & 1 & 2 \\
\hline & LChl & relative chlorophyll concentration per leaf area & SPAD unit & 87 & 12 & 41 & 12 & 68 \\
\hline & LCC & leaf carbon concentration & $\%$ & 95 & 34 & 46 & 4 & 62 \\
\hline & LNC & leaf nitrogen concentration & $\%$ & 95 & 0.6 & 1.2 & 0.5 & 2.7 \\
\hline \multirow[t]{6}{*}{ leaf chemical } & LPC & leaf phosphorus concentration & $\%$ & 96 & 0.03 & 0.12 & 0.08 & 0.50 \\
\hline & $\mathrm{LMgC}$ & leaf magnesium concentration & $\%$ & 96 & 0.14 & 0.66 & 0.43 & 2.14 \\
\hline & $\mathrm{LCaC}$ & leaf calcium concentration & $\%$ & 96 & 0.24 & 1.66 & 1.10 & 4.80 \\
\hline & $\mathrm{RCC}$ & root carbon concentration & $\%$ & 90 & 44 & 51 & 4 & 72 \\
\hline & $\mathrm{RNC}$ & root nitrogen concentration & $\%$ & 90 & 0.19 & 0.87 & 0.55 & 3.53 \\
\hline & RPCs & root phosphorus concentration & $\%$ & 89 & 0.01 & 0.07 & 0.04 & 0.18 \\
\hline \multirow{3}{*}{ root chemical } & $\mathrm{RKC}$ & root potassium concentration & $\%$ & 89 & 0.09 & 0.99 & 0.87 & 4.34 \\
\hline & $\mathrm{RMgC}$ & root magnesium concentration & $\%$ & 89 & 0.05 & 0.41 & 0.30 & 1.25 \\
\hline & $\mathrm{RCaC}$ & root calcium concentration & $\%$ & 89 & 0.04 & 0.87 & 0.83 & 4.45 \\
\hline
\end{tabular}




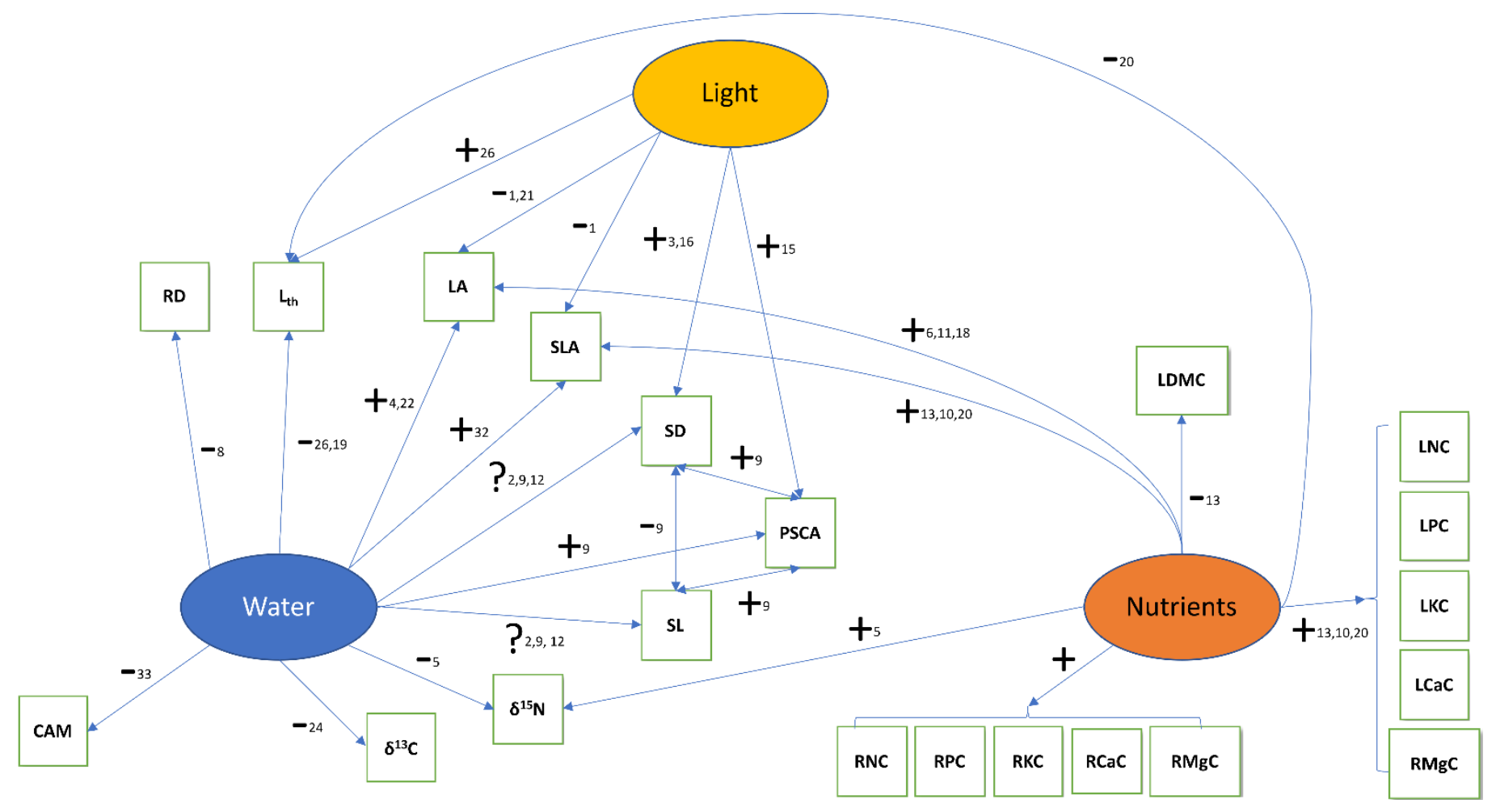

Figure 1. Expectations regarding the direction of the trait-environment relationships for epiphytes along (micro-) environmental gradients of water, nutrient, and light availability at the local scale. "+": positive relationship, "-": negative relationship, "?": direction of relationship unclear. Trait abbreviations are explained in Table 1. Numbers refer to publications that established these links and which are listed in the supplement. For a full list of traits, see Table 1.

Members of two important epiphyte families (Orchidaceae and Araceae) often have thick roots with a velamen radicum (a typically multilayered root epidermis composed of dead cells at maturity, [33]), which is thought to allow rapid water uptake and prevent water loss. Therefore, velamen thickness and, thus, root diameter are expected to decrease with improved water availability [34], although there is also conflicting evidence [24]. Expectations regarding stomatal density and size are not straightforward. These traits are negatively correlated with each other and an increase in either of them increases maximal stomatal conductance $\left(\mathrm{g}_{\mathrm{smax}}\right)$ which, everything else being equal, should be reduced under water scarcity [35]. However, which of the two parameters drives gsmax (here approximated by percent stomatal complex area, PSCA) may depend on the studied system [25,35-37]. Moreover, $\mathrm{g}_{\mathrm{smax}}$ should also increase in response to light availability [38]. At exposed sites in the canopy, both light intensity and vapor pressure deficit are increased, i.e., water availability is decreased. While in the case of various leaf traits (e.g., specific leaf area, leaf thickness) both environmental factors drive the trait into the same direction from less to more exposed sites (Figure 1), for $\mathrm{g}_{\text {smax }}$ the two factors lead to opposing trends [39]. Empirical evidence for woody angiosperms indicates that, at the local scale, light intensity has a stronger effect on $g_{\text {smax }}$ than VPD. Figure 1 focuses on three abiotic factors: water, light, and nutrients. However, trait matching between tree and epiphyte species may be driven by other tree traits unrelated to these factors. For example, substrate stability (influenced by bark loss rates, wood density, or tree longevity) may filter for fast relative growth rates or small final plant size of epiphytes. Substrate smoothness could be correlated with certain diaspore traits that facilitate attachment to the bark or with root traits related to attachment.

Trait-environment relationships are generally rather weak (e.g., [32]). Along coarsescale gradients of soil properties and macroclimate there is much unexplained variability, 
presumably because these gradients do not adequately capture fine-scale variation in soil conditions and microclimate that actually influence community assembly via species filtering [40]. Moreover, even within any given local plant community there is substantial trait variation, because (1) within relatively homogeneous vegetation stands there are still environmental gradients (e.g., [3]) and (2) for any possible set of abiotic conditions various ecological strategies / trait combinations can be successful [41]. Despite this intracommunity variability, community weighted trait means (CWMs) have been repeatedly found to reflect local- or regional-scale environmental gradients (e.g., [30,42,43]). We also use CWMs to infer assemblage differences between tree species.

Apart from average trait values the diversity of functional traits (FD) may also vary among plant communities due to convergence or divergence of traits [44]. How functional diversity responds to gradients of productivity and disturbance is still unclear (e.g., [43,45]). However, in the context of epiphyte assemblages, we would expect trait convergence on tree species that offer adverse conditions to epiphytes (e.g., very open or dense crowns or very smooth bark), while trait divergence should be observed in tree species that offer a large range of abiotic conditions because, e.g., their crown architecture allows for the formation of crotches filled with organic material or gradual light attenuation within the crown.

The strength of the effect of a tree species on epiphyte traits should increase vertically from the stem base to the outer crown [46]. For example, while VPD and light availability in tree crowns may be strongly influenced by foliage density, in the understory these variables are primarily determined by the surrounding vegetation [47]. Conversely, species-specific differences on tree trunks regarding bark structure should be much less pronounced in the crown because of a correlation between bark rugosity and age of trunk and branches. This variation asks for a zone-based sampling approach [48].

One important goal of plant functional trait research is to detect and understand patterns of trait coordination. Wright et al. [32] described a global leaf economics spectrum (LES) in which leaf traits align along a one-dimensional axis from an acquisitive strategy (low longevity but high SLA and mass based nutrient concentrations, photosynthesis, and respiration rates) to a conservative strategy (with high longevity and low values for the other traits). Recently, the focus has shifted to non-foliar traits (e.g., root and stem traits) (e.g., [49-51]) with attempts to integrate several trait types for a holistic understanding of plant ecological strategy [52-54], leading to the postulation of a general "fast-slow" economic spectrum integrating root, stem and leaf traits [53]. This implies a root economics spectrum (RES) analogous to the LES [50], although at least for some plant groups empirical evidence suggests that trait relationships are more complex for underground organs than for leaves $[51,55,56]$. Figure 2 summarizes reported trait correlations for those traits that were studied in the present work.

Due to the scarcity of trait data of epiphytes it is currently unclear whether the trait correlations in Figure 2, established for terrestrial plants, also apply or whether slope or directionality of trait relationships differ because of some peculiarities of the epiphytic habitat. First, one of the central traits is adult plant height, as it is closely related to competitive ability in a closed vegetation (e.g., [52,57]). However, as epiphytes use other plants as support, their size is uncorrelated to the light environment, which is why Westoby et al. excluded "height-parasites" (climbers and epiphytes) from their theoretical considerations. Second, many epiphytes cling directly to bare bark, i.e., they have no body of substrate in which they could bury their roots. Such roots have to solve the problems of high water-loss through evaporation and intermittent water supply, and we expect substantial differences regarding root trait coordination. Moreover, a vertical or even overhanging substrate will pose very different challenges in terms of attachment. 


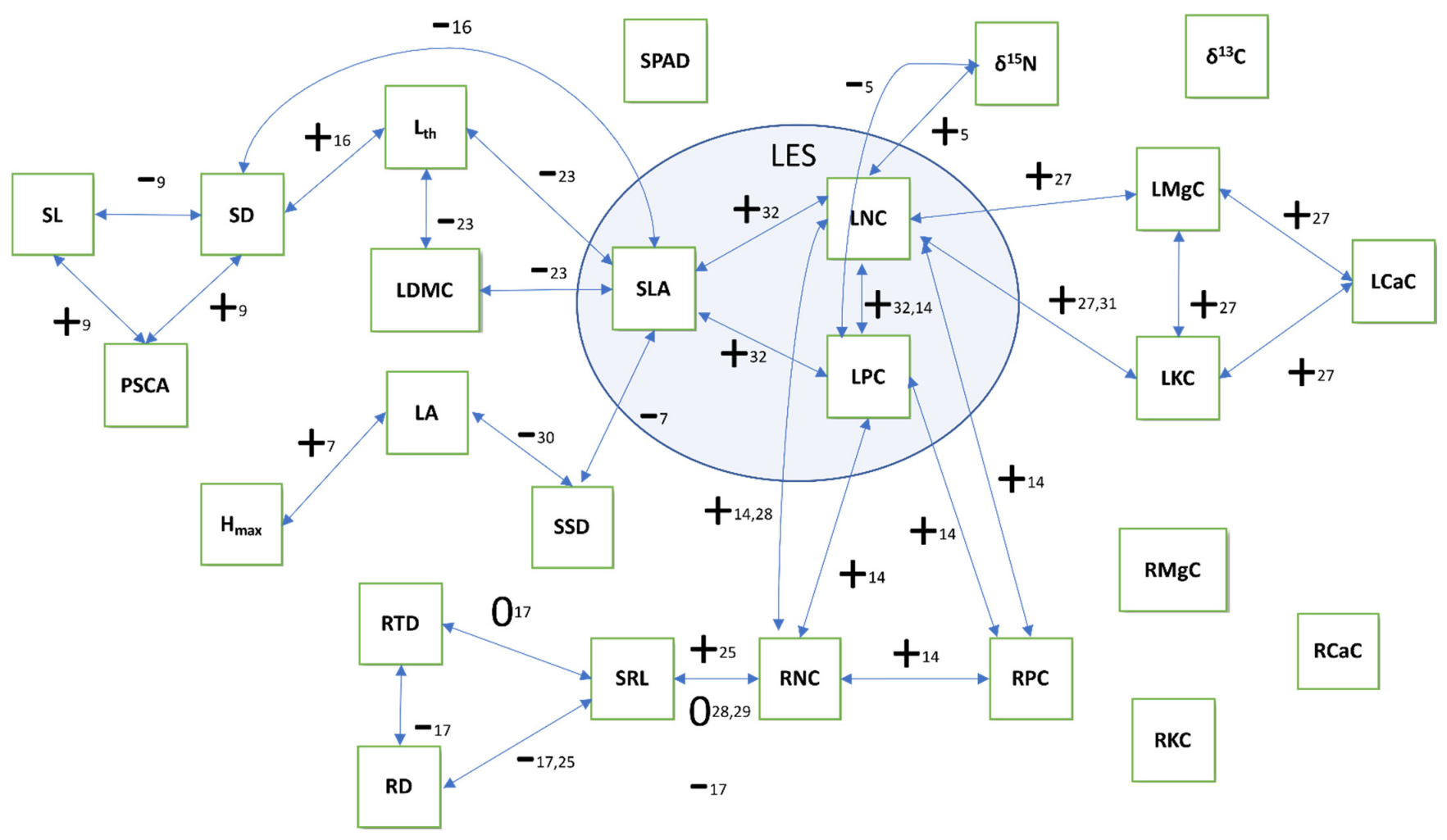

Figure 2. Expectations regarding correlations between the studied traits. Trait abbreviations are explained in Table 1. The traits in the inner circle are part of the classical leaf economics spectrum (LES). Arrows indicate reported relationships between traits in the literature. "+": positive relationship, "-": negative relationship, "0": no relationship. Numbers refer to publications that established these links, and which are listed in the supplement. For a full list of traits and abbreviations, see Table 1.

The aims of the present study were threefold. Firstly, to describe broad trait correlations for the epiphyte assemblages at the study site based on a large set of functional traits. This should allow first insights in possible idiosyncrasies regarding epiphyte trait coordination. Secondly, whether tree species exert habitat filtering is assessed by comparing community weighted means of a large range of functional traits among assemblages on different tree species. Third, we compare the functional diversity of epiphyte traits and community-based metrics on different tree species.

\section{Materials and Methods}

\subsection{Study Site and Focal Tree Species}

Sampling for trait measurements and determination of epiphyte abundances on the focal tree species took place in the San Lorenzo forest reserve, a 12,000-ha reserve on the Caribbean slope of Panama $\left(9^{\circ} 17^{\prime} \mathrm{N}, 79^{\circ} 58^{\prime} \mathrm{W}, 130 \mathrm{~m}\right.$ a.s.l.). Mean annual air temperature and precipitation in this lowland rainforest are $25.2{ }^{\circ} \mathrm{C}$ and $3360 \mathrm{~mm}$ [58]. A detailed description of the forest is given by Wright et al. [59] and a detailed description of the epiphyte flora can be found in Zotz and Schultz [60]. A 6-ha permanent plot for trees is run by the Center for Tropical Forest Science (CTFS-ForestGeo; [61]), of which 0.9 ha are accessible with a canopy crane. We chose four tree species, all of them tall growing trees (reaching ca. 35-40 m) and among the most abundant species at the study site, which allowed for a large replication: Aspidosperma spruceanum Benth. ex Müll.Arg. (Apocynaceae), Brosimum utile (Kunth) Oken (Moraceae), Calophyllum longifolium Willd. (Clusiaceae) and Manilkara bidentata (A.DC.) A.Chev. (Sapotaceae). Per tree species, we sampled 20-21 individuals with a dbh $>40 \mathrm{~cm}$, counting the number of epiphytes per species (99 species were found) and Johansson zone (JZ). Johansson zones divide the tree into lower and upper trunk (JZ1 and JZ2) and inner, middle and outer crown (JZ3-JZ5, [46]). 
All sampled trees were located within a continuous area of ca. 40 ha. Sampling protocol and composition of the epiphyte assemblages are described in detail in Wagner and Zotz [47]. Several differences among these tree species seem relevant in the context of epiphyte host specificity. Annual dbh increment in Calophyllum $\left(0.21 \mathrm{~cm}_{\text {year }}^{-1}\right)$ is much higher than in the other species $\left(0.12-0.15 \mathrm{~cm}_{\text {year }}{ }^{-1},[47]\right)$, whereas the estimated longevity is much lower (253 years; Aspidosperma: 468 years, Manilkara: 552 years, Brosimum: 637 years). Bark rugosity also differs strongly [47]: Brosimum bark is smooth, Aspidosperma bark is rougher especially in the lower trunk of large trees, with large cracks. Both Calophyllum and Manilkara possess vertically fissured bark, with large individuals of the latter species having the deepest fissures. Finally, Brosimum and Calophyllum have more open crowns, while the largest crown extension is found in Manilkara [47].

\subsection{Functional Traits of Epiphytes}

We determined 28 functional traits. Depending on the particular trait, data for 87-99 locally occurring epiphyte species could be collected (Table 1). Sampling took place during the rainy season (July-November 2018). We generally aimed at sampling five mature conspecifics, growing in typical microsites. While this goal was even surpassed in some cases, replication was much smaller in rare species. In the extreme case, a species "average" is based on a single observation. To check such values for plausibility, observations were compared to those of other species in the same family. All values were in the expected range. For two species of leafless cacti (Epiphyllum phyllanthus (L.) Haw. and Weberocereus tunilla (F.A.C. Weber) Britton \& Rose) all leaf trait observations were performed on stems [62], except for maximum leaf area.

Plant height was measured in the field as the shortest distance between the point of attachment and the upper or, in pendant species, lower boundary of the main photosynthetic tissue. The maximum plant height $\left(\mathrm{H}_{\max }\right.$, Table 1$)$ refers to the maximum observed plant height of a species. Per individual, we collected 1-4 leaves, a section of the stem or rhizome and a representative root sample. To prevent desiccation, samples were transported to the laboratory in closed plastic bags, where plant parts or detached leaves were immediately placed in containers with deionized water for rehydration and root samples were stored at $4{ }^{\circ} \mathrm{C}$. All samples were processed within $24 \mathrm{~h}$.

We removed the petiole from leaves, determined fresh weight, performed the measurements described below and dried samples at $75^{\circ} \mathrm{C}$ for $>48 \mathrm{~h}$ before determining dry weight. Depending on leaf size, a precision scale (Torbal AG500, Scientific Industries Inc., Bohemia, NY, USA), an analytical balance (Torbal AGN 200, Scientific Industries Inc., Bohemia, NY, USA) or a micro-analytical balance (XPE26, Mettler Toledo, Columbus, $\mathrm{OH}, \mathrm{USA}$ ) were used. Leaf dry matter content (LDMC) was calculated as leaf dry weight divided by leaf fresh weight. Photographs of each leaf (EOS 750D, Canon, Tokyo, Japan) allowed area determination with ImageJ [63], which was used to determine specific leaf area (SLA, leaf area/dry weight) for each leaf sample and maximum leaf area (LA $\left.\mathrm{Lax}_{\max }\right)$ for each species. Leaf thickness $\left(\mathrm{L}_{\mathrm{th}}\right)$ represents the average of three measurements with an electronic micrometer (IP 54, Helios-Preisser, Gammertingen, Germany) in the central part of the leaf, avoiding major veins. Leaf chlorophyll concentration per leaf area (LChl) was approximated with an optical meter (SPAD-502, Konica Minolta Sensing, Inc., Sakai, Osaka, Japan), averaging three readings in the central part of the leaf. Stomatal traits were studied with a thin layer of nail polish applied to the central part of the lower and upper sides of leaves. Micrographs of the impressions were taken with a digital microscope camera (DP73) attached to a microscope (BX53) and analyzed with the cellSens Standard software (all Olympus K.K., Tokyo, Japan). We determined stomatal density (SD, averages of three micrographs per impression), length (SL) and width (SW; averages of three stomata per impression). For four amphistomatal species, SD was taken to be the sum of the stomatal densities of both leaf sides. Percent stomatal complex area (PSCA) was calculated as $\mathrm{PSCA}=\mathrm{SD} \times \frac{1}{4} \pi(\mathrm{SL} \times \mathrm{SW}) \times 100[64]$. 
Root trait measurements were performed on a representative sample of the entire root system of each plant and not only on fine roots (i.e., diameter $<2 \mathrm{~mm}$ ), because epiphytes do not have the same clear-cut functional differentiation regarding absorptive fine roots and non-absorptive transport roots as terrestrial plants. Zotz and Winkler [65] showed experimentally that Phalaenopsis orchids can take up nutrients over the entire root length and not just at the root tips as in terrestrial plants. Moreover, the roots of many epiphytes have no or little ramifications and in some velamentous species roots invariably exceed $2 \mathrm{~mm}$ in diameter. Fresh, cleaned roots were photographed (without overlap), dried at $75^{\circ} \mathrm{C}$ for $>48 \mathrm{~h}$ and weighed. Using WinRHIZO ${ }^{\mathrm{TM}}$ (Regent Instruments, Québec, Canada), photographs were used to determine specific root length (SRL, root length/root dry mass), average root diameter (RD) and root tissue density (RTD, root dry mass/root volume).

The volume of fresh stems or stem sections was determined via water displacement [62]. For small samples, we used pycnometers $\left(25 \mathrm{~cm}^{3}\right.$ and $100 \mathrm{~cm}^{3}$, BLAUBRAND ${ }^{\circledR}$, BRAND GmbH, Wertheim, Germany) to increase accuracy. For species without upright stems, we sampled the rhizome. In the case of orchids with pseudobulbs, we sampled these 'thickened' stems (i.e., thickened stems, [66]). Ideally, sampled stem sections were $10 \mathrm{~cm}$ long. When stems or rhizomes were much smaller, several sections were combined for measurements. Afterwards, stems were dried at $75^{\circ} \mathrm{C}$ for at least $72 \mathrm{~h}$, dry mass was determined, and stem specific density (SSD) was calculated as stem dry mass divided by the volume of the fresh stem.

For determination of leaf and root nutrient concentrations and foliar isotope ratios, oven-dried samples were ground with a ball mill (small samples: TissueLyser II, QIAGEN N.V., Venlo, Netherlands; larger samples: MM 400, Retsch, Haan, Germany). In a few cases, samples of several individuals had to be combined for chemical analyses. Leaf nitrogen concentration (LNC) and leaf nitrogen $\left(\delta^{15} \mathrm{~N}\right)$ and carbon $\left(\delta^{13} \mathrm{C}\right)$ isotope ratios were determined by elemental analyzer-isotope ratio mass spectrometry (Delta PLUS; Thermo Electron, Bremen, Germany). As universal standards, atmospheric air was used for ${ }^{15} \mathrm{~N}$ and the Vienna Pee Dee Belemnite for ${ }^{13} \mathrm{C}$. Leaf $\delta^{13} \mathrm{C}$ was used as a general proxy for leaf water use efficiency (WUE) across $C_{3}$ and CAM plants because (i) both WUE and $\delta^{13} \mathrm{C}$ are much higher in CAM species than in C3 species, (ii) $\delta^{13} \mathrm{C}$ and WUE in CAM species scales positively with the extent of nocturnal $\mathrm{CO}_{2}$ fixation via PEPC, and (iii) $\delta^{13} \mathrm{C}$ and WUE in $\mathrm{C}_{3}$ species scale also positively with diffusional limitation of photosynthetic $\mathrm{CO}_{2}$ fixation. Based on the $\delta^{13} \mathrm{C}$ values we also determined one categorical trait, namely photosynthetic pathway (PP), classifying epiphytes in CAM (at least some $\delta^{13} \mathrm{C}$ values $\geq-21 \%$ ) and $\mathrm{C}_{3}$ species (all $\delta^{13} \mathrm{C}$ measurements $<-21 \%$ ). Root nitrogen concentration (RNC) was determined with an elemental analyzer with a thermal conductivity detector (Flash EA 1112, Thermo Fisher Scientific, Milano, Italy) according to manufacturer's recommendations and using copper and tungsten oxide as catalysts and acetanilide as standard. To determine leaf and root $\mathrm{P}, \mathrm{K}, \mathrm{Ca}$ and $\mathrm{Mg}$, approximately $5 \mathrm{mg}$ of a sample were digested in $200 \mu \mathrm{L}$ concentrated $\mathrm{HNO}_{3}$ and $30 \mu \mathrm{L} \mathrm{30 \%} \mathrm{H}_{2} \mathrm{O}_{2}$ and filled up to $1 \mathrm{~mL}$ with distilled water [67]. Leaf (LPC) and root (RPC) phosphorus concentrations were determined colorimetrically in an aliquot of $0.1 \mathrm{~mL}$ of the digestion solution [68]. The absorption by the molybdenumphosphorus complex was measured at $710 \mathrm{~nm}$ using a UV-VIS spectrophotometer (Specord 50, Analytik Jena, Jena, Germany). Concentrations of potassium, calcium, and magnesium in leaves and roots ( $\mathrm{LKC}, \mathrm{RKC}, \mathrm{LCaC}, \mathrm{RCaC}, \mathrm{LMgC}, \mathrm{RMgC})$ were determined with a flame atomic absorption spectrometer (240 AA, Agilent technologies, Mulgrave, Australia) with element-specific hollow-cathode lamps and an acetylene flame according to manufacturer's recommendations regarding wavelength and slit settings.

\subsection{Data Analysis}

All statistical analyses were carried out with R version 3.5.2 [69]. Graphs were produced using the R package ggplot2 [70].

To account for the approximate log-normal distribution of most traits, data were $\log _{10}$-transformed. Exceptions were LChl, $\delta^{15} \mathrm{~N}$ and $\delta^{13} \mathrm{C}$ where data were approximately 
normally distributed. The proportion of $\mathrm{C}_{3}$ species in an assemblage (PP_C3) was arcsine square root transformed. Species averages were used in all analyses.

To assess bivariate trait relationships, we first run Pearson's correlation analyses visualizing the correlation matrix with the corrplot.mixed function of the corrplot package version 0.84 [71]. To analyze trait coordination in the epiphyte assemblage, we conducted principal component analyses (PCA) with the PCA function of the FactoMineR package version 2.0 [72] scaling variables to unit variance before analysis. PCA graphs were produced with the factoextra package version 1.0.5 [73]. A first PCA was run with a maximum of traits including almost all continuous traits except LChl (i.e., 26 traits). After removing epiphyte species with missing values for any trait, a species-trait-matrix with 72 epiphyte species was obtained. Hymenophyllaceae lack roots and stomata. We thus ran an additional PCA on a dataset without root and stomatal traits, to locate Hymenophyllaceae and some other species with missing observations in the trait space of the remaining 14 traits (81 species).

To calculate community-weighted means (CWMs, e.g., [74]), we defined an epiphyte "community" as the epiphyte assemblage on the trunk or in the crown of an individual tree and divided the epiphyte dataset in a trunk dataset (Johansson zones 1-2) and a crown dataset (Johansson zones JZ3-5). Of the 99 epiphyte species for which we determined trait values, only 76 also occurred on the sampled trees (trunk: 54, crown: 65). Some Hymenophyllaceae were found on the sampled trees but were excluded from analysis because no individual abundance data were available. Likewise, a few epiphyte species occurring on the sampled trees (all rare species accounting together for $<1 \%$ of the total number of epiphytes in the dataset) were not represented in the traits dataset and therefore also excluded. Only assemblages with at least 10 epiphyte individuals per tree individual (trunk or crown zone) were considered. The resulting number was 20,21, 17, and 20 crown and 7, 12, 9 and 16 trunk assemblages for Aspidosperma, Brosimum, Calophyllum, and Manilkara, respectively. CWMs were calculated with the dbFD function of the FD package $[75,76]$ for all 27 continuous traits plus photosynthetic pathway (PP_C3, a binary trait). In this case, "CWM" refers to the relative abundance of $\mathrm{C}_{3}$ species per assemblage. The $\mathrm{dbFD}$ function was also used to calculate the multivariate functional diversity indices "functional dispersion" [75], "functional evenness" and "functional divergence" [77], which describe different facets of functional diversity. Functional dispersion is a measure of the trait spread in multidimensional trait space being "the mean distance in multidimensional traits space of individual species to the centroid of all species." Functional evenness is based on the minimum spanning tree that links all species in the multidimensional trait space and measures the regularity with which the trait space is filled by species, weighted by their abundance. Finally, functional divergence measures the divergence of the abundance distribution in the trait space by using an index that quantifies how species diverge in their distances (weighted by their abundance) from the center of gravity in the trait space.

To assess whether CWMs differed significantly with tree species, we performed PCAs on the CWMs of individual tree assemblages (separately for crown and trunk assemblages) and revised the clustering of trees of the same species. We then tested for significant differences among PC scores of the focal tree species on PC 1 and PC 2.

Besides this multivariate approach, we also tested whether CWMs differed significantly with tree species by performing pairwise comparisons. We visually assessed whether the response variable residuals were approximately normally distributed with Q-Q plots. Whenever Bartlett's test indicated homogeneous variances, we used ANOVA followed by Tukey's tests. Otherwise, Welch's heteroscedastic F test followed by max-t tests for multiple comparisons using the multcomp and sandwich packages $[78,79]$ were used. The same approach was used to test for differences regarding functional diversity indices as a function of host tree species. 


\section{Results}

\subsection{Epiphyte Trait Values and Trait Covariation}

Average species values are given for all continuous traits in Table 1 and bivariate correlations between the studied traits in Figure $\mathrm{S} 1 . \mathrm{H}_{\max }$ showed a pronounced positive correlation with LA $(r=0.79)$, a weaker positive correlation with LDMC and weak negative correlations with SLA, $\mathrm{L}_{\text {th }}$ and SRL. Larger leaves tended to be thinner with higher LDMC. SLA had a moderate, negative correlation with its two components, $\mathrm{L}_{\text {th }}$ and LDMC [62] and, in accordance with the LES, a moderate (LPC) to strong (LNC) positive correlation with leaf nutrients (Figure S3). Moreover, in accordance with a whole-plant "fast-slow" economic spectrum SLA showed a moderate, positive correlation with SRL [53], but no correlation with SSD or SD. SD and SL are inevitably strongly negatively correlated [35, $r=-0.74$ in our dataset], but PSCA only increased with SD $(r=0.47)$. Nutrient concentrations of leaves and roots were generally positively correlated among each other and negatively correlated with LCC and RCC (Figure S3). Strong, positive correlations among leaf nutrients were observed for $\mathrm{N}, \mathrm{P}$ and $\mathrm{K}(\mathrm{r}=0.47-0.71)$, $\mathrm{Ca}$ and $\mathrm{Mg}(\mathrm{r}=0.62)$ and $\mathrm{K}$ and $\mathrm{Mg}(\mathrm{r}=0.39)$. In contrast, leaf Ca was not correlated with leaf $\mathrm{N}, \mathrm{P}$, and $\mathrm{K}$ and leaf $\mathrm{Mg}$ was uncorrelated to leaf $\mathrm{N}$. Correlations between nutrient concentrations were stronger in roots than in leaves with positive relations among all nutrients, being strongest between root $\mathrm{K}, \mathrm{P}$, and $\mathrm{Mg}$ $(\mathrm{r}=0.80-0.84)$ and $\operatorname{root} \mathrm{N}$ and $\mathrm{P}(\mathrm{r}=0.75)$. Nutrient concentrations of leaves and roots were also positively correlated, from moderate $(K, r=0.32)$ to strong $(N, r=0.65)$. Leaf $\delta^{13} \mathrm{C}$ increased with $\mathrm{L}_{\mathrm{th}}(\mathrm{r}=0.56)$ and decreased with leaf $\mathrm{N}$ and SLA $(\mathrm{r}=0.48$ and 0.43$)$. Foliar $\delta^{15} \mathrm{~N}$ increased with LNC $(\mathrm{r}=0.54)$. The only variable correlated with SSD was LDMC $(r=0.24)$. The strongest bivariate correlation was found for SRL and RD $(r=-0.94)$. SRL was also positively correlated with RTD $(r=0.41)$, while RD was negatively correlated with $\operatorname{RTD}(r=-0.69)$.

A large proportion (65\%) of the variation of 26 functional traits was captured by the first four principal components of a PCA (Figure 3A,B, Table S1). The first principal component (PC 1, explained variation $26 \%$ ) was most closely correlated with mass-based nutrient concentrations-especially in roots. The second principal component (explained variation $18 \%$ ) was closely correlated to SRL (loading: 0.88 ) and RD (loading: -0.93 ), whereas RTD was correlated to both, PC 1 and PC 2 (Figure 3A,B, Table S1). PC 3 (explained variation $12 \%$ ) was closely correlated to maximal leaf area and plant height. Stomatal density and length were closely correlated to PC 4 (explained variation 9\%). Leaf thickness was very well captured by PC 3 and 4 , whereas SLA was most closely correlated to PC 2 but almost equally close to PC 1 and 4 and LDMC was best captured by PC 1 and 3. Plant families partly separated in trait space defined by PCs $1-4$ (Figure 3C,D). Orchids and especially aroids had low SRL and high RD, due to their velamen radicum, occupying the lower part of the ordination plot spanned by PC 1 and 2. Due to high tissue nutrient concentrations, Piperaceae (all genus Peperomia) and Araceae (all genus Anthurium) clustered at the right-hand side of the PC 1-2 plot, but separated along PC 2 (i.e., Peperomia species had higher SRL).

Running a PCA without stomatal and root traits allowed the inclusion of nine additional species, especially six Hymenophyllaceae. In this PCA, PC 1 (explained variance $28 \%$ ) was closely correlated to leaf nutrient concentration (e.g., loading of LNC: 0.78, Table $\mathrm{S} 1$, Figure $\mathrm{S} 2 \mathrm{~A}$ ), while $\mathrm{L}_{\text {th }}$ showed a very close correlation with PC 2 (explained variance $22 \%$, loading 0.84 ). PC 3 was again well described by $\mathrm{LA}_{\max }$ and $\mathrm{H}_{\max }$ and PC 4 by SSD (Table S1, Figure S2B). The very thin foliage of filmy ferns led to a clear separation from other families along PC 2, while the high values of leaf P and $\mathrm{K}$ in some Peperomia species explain again the extreme position along PC 1 (Figure S2C). 

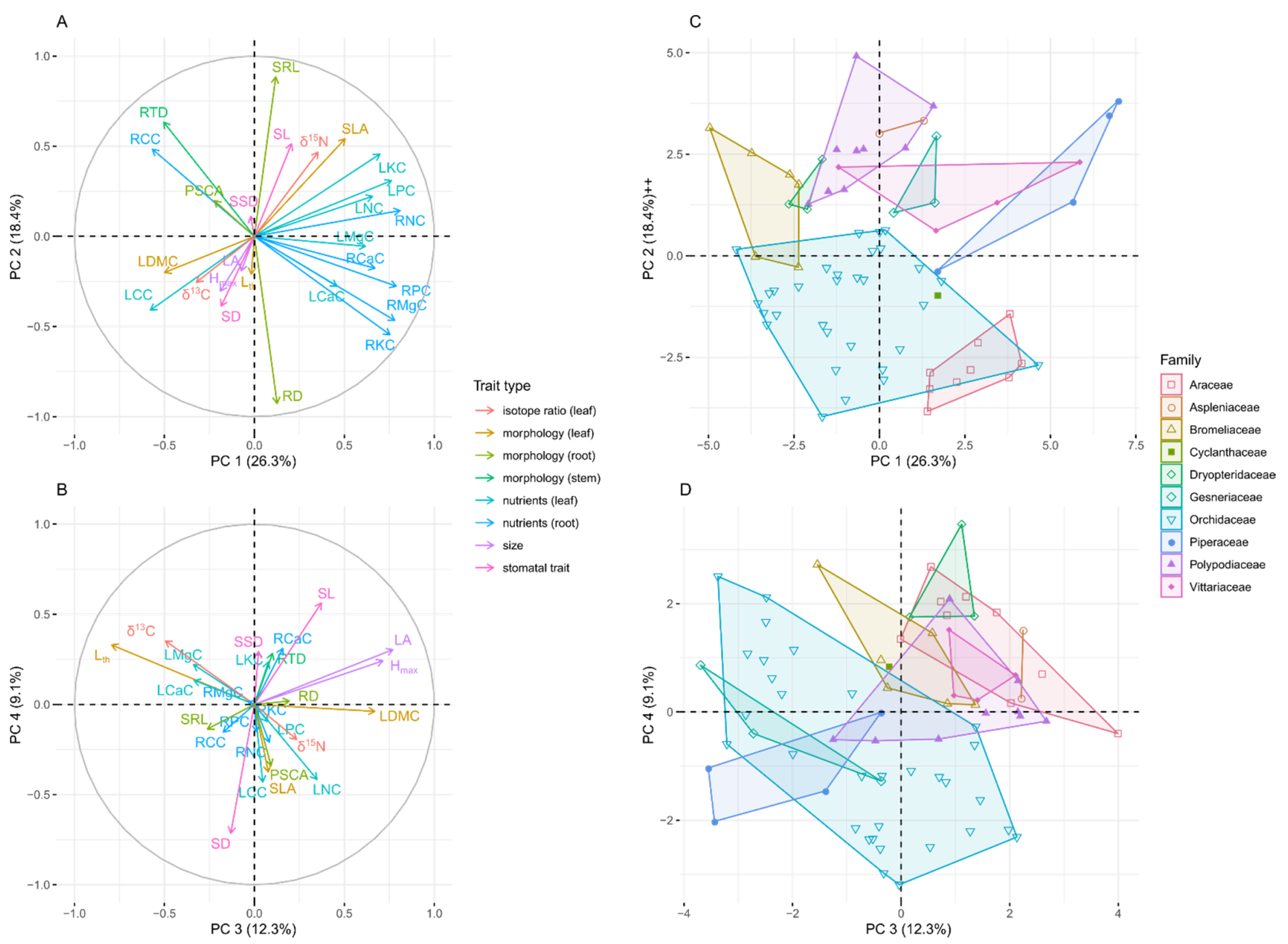

Figure 3. Principal component analysis of functional traits of the San Lorenzo epiphyte community. Data are species averages for 26 functional traits of 72 epiphytic species. A and B: Variable correlation plots for the first and second principal component (A) and the third and fourth principal component (B), respectively. Colors identify trait types. Trait abbreviations are given in Table 1. C and D: Epiphyte species within the ordination space. (C) first and second principal component, (D) third and fourth principal component. Colors identify plant families, which are enclosed by convex hulls.

\subsection{Differences among Tree Species}

The trait values of crown epiphyte assemblages differed among tree species (Figure 4B, Table S2), the first four PCA axes capturing almost $80 \%$ of the variability in the CWMs of 28 traits. PC 1 (explained variability 32\%) was most strongly correlated with root nutrient traits (especially root $\mathrm{K}$ and $\mathrm{Mg}$, loadings $>0.9$, Table S2), as well as RD and RTD (loadings: 0.86 and -0.82 ), while LKC, SD and SL (loadings: $0.87,-0.93,0.86$ ) followed by LDMC, SLA and $\mathrm{L}_{\text {th }}$ (loadings: $-0.73,-0.69$, and 0.75 ) were traits that strongly correlated with PC 2 (explained variability 25\%). Assemblages on Brosimum had significantly lower PC scores along PC 1 than those on the other tree species (ANOVA, $F=9.94, d f=3, p<0.001$, followed by Tukey's Test). Along PC 2, assemblages on Brosimum had higher PC scores than those on Manilkara (ANOVA, $F=3.11, d f=3, p=0.03$, followed by Tukey's Test). 

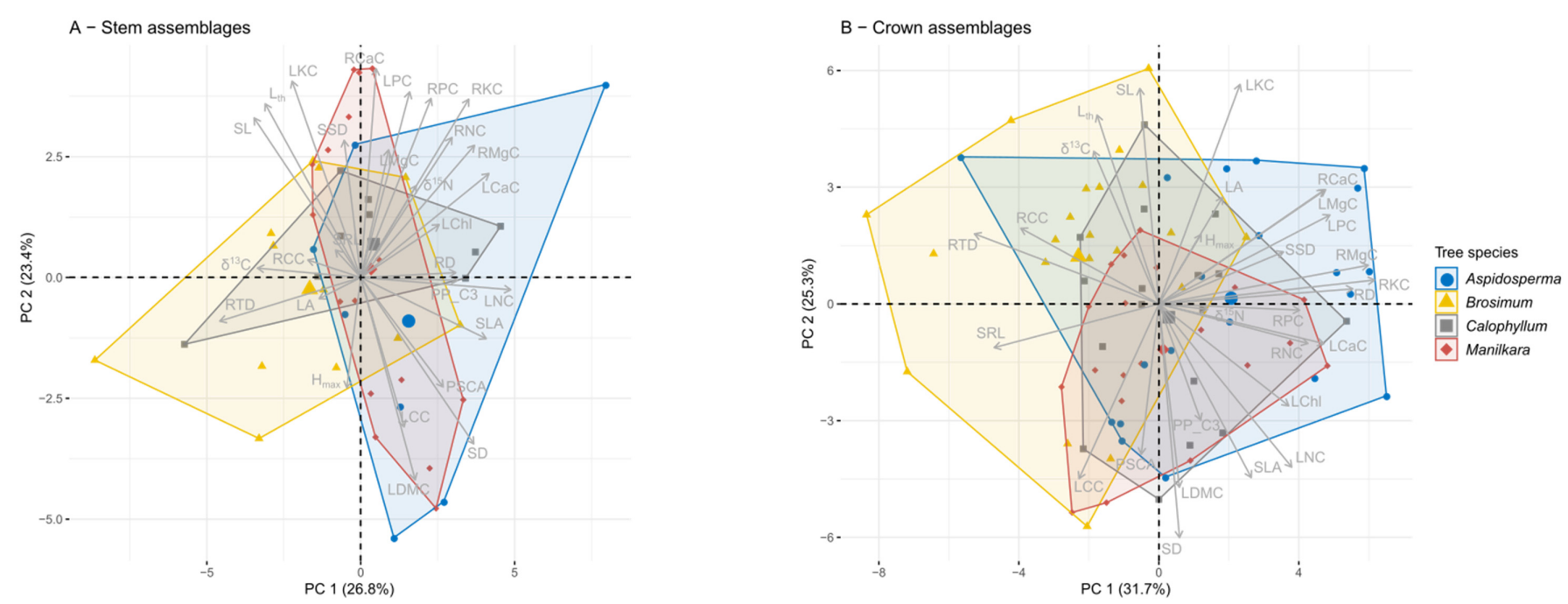

Figure 4. Principal component analysis of CWMs of functional traits of the San Lorenzo epiphyte community on tree stems (A) and tree crowns (B). Analyzed data are based on species averages for 28 functional traits. Trait abbreviations are given in Table 1. Tree species are differentiated by color and enclosed by convex hulls. Group centroids are indicated by larger symbols.

For stem epiphyte assemblages, tree species had no effect on PC scores (Figure 4A, Welch's ANOVA, PC 1: $F=1.85, d f=3, p=0.18$; PC 2: $F=0.91, d f=3, p=0.45$ ). In line with this finding, the CWMs of the trunk assemblages of the four tree species differed in a single trait: LChl had lower CWMs on Brosimum than on Manilkara (Table S3, Figure S3). In stark contrast, the CWMs of the crown assemblages differed significantly among tree species for 20 out of 28 traits (Table S3, Figure S4). Significant pairwise differences were most often observed between assemblages on Brosimum and Aspidosperma (15 traits), followed by Brosimum vs. Calophyllum and Brosimum vs. Manilkara (eight traits, Table S2, Figure S3), while pairwise differences between the other three species were rare (ManilkaraAspidosperma, five traits, and Manilkara-Calophyllum and Calophyllum-Aspidosperma, three traits each). Moreover, CWMs of epiphyte assemblages were most distinct on Brosimum (37\% of all pairwise comparisons, 31/84 trait comparisons), followed by Aspidosperma ( $27 \%$, 23/84), Manilkara (19\%, 16/84) and Calophyllum (17\%, 14/84). Brosimum therefore imposed the strongest filtering on their epiphyte assemblage. Regarding leaf morphological traits, assemblages on Brosimum had, on average, lower LDMC and higher $\mathrm{L}_{\text {th }}$ than those on Aspidosperma and Calophyllum, indicating a higher proportion of species with succulent leaves. Because of higher leaf thickness and lower LDMC, SLA was also lowest on Brosimum. Compared to epiphytes on Aspidosperma, those on Brosimum showed lower CWMs for several nutrients in leaves ( $\mathrm{N}$ and $\mathrm{P}$ ) and roots $(\mathrm{N}, \mathrm{K}$, and $\mathrm{Mg}$ ). For leaf $\mathrm{N}$ and $\mathrm{LChl}$, this difference was also significant in regard to the other two tree species, while leaf P CWMs of Calophyllum and Manilkara were not higher than those of Brosimum. For the stomatal traits, CWMs of SD were lower, and CWMs of SL were higher on Brosimum than on Manilkara, but there were no differences for PSCA. Pronounced differences were observed for root traits. CWMs of SRL were highest on Brosimum and lowest on Aspidosperma while the reverse was true for RD; CWMs of RTD were significantly higher for Brosimum compared to Aspidosperma and Manilkara. Finally, clear differences were observed in the CWMs of $\delta^{13} \mathrm{C}$. When all species $\left(\mathrm{C}_{3}\right.$ and CAM plants) were included, $\delta^{13} \mathrm{C} C W M$ s on Brosimum were significantly higher than those on Manilkara. When only $\mathrm{C}_{3}$ plants were considered $\left(\delta^{13} C_{-} 2\right)$, Brosimum had still the highest values and those of Aspidosperma and Calophyllum were significantly more negative.

Functional dispersion of crown epiphyte assemblages tended to be larger on Aspidosperma (i.e., larger spread in the multidimensional traits space) than on Brosimum ( $p=0.052$, Tukey's Test), while all other pairwise differences were not significant (Figure 5A). Compared to assemblages on the other tree species, functional evenness on Aspidosperma 
was also higher, while there were no differences in functional divergence related to tree species (Figure 5B,C). For trunk assemblages, none of the diversity indices differed with tree species (results not shown).
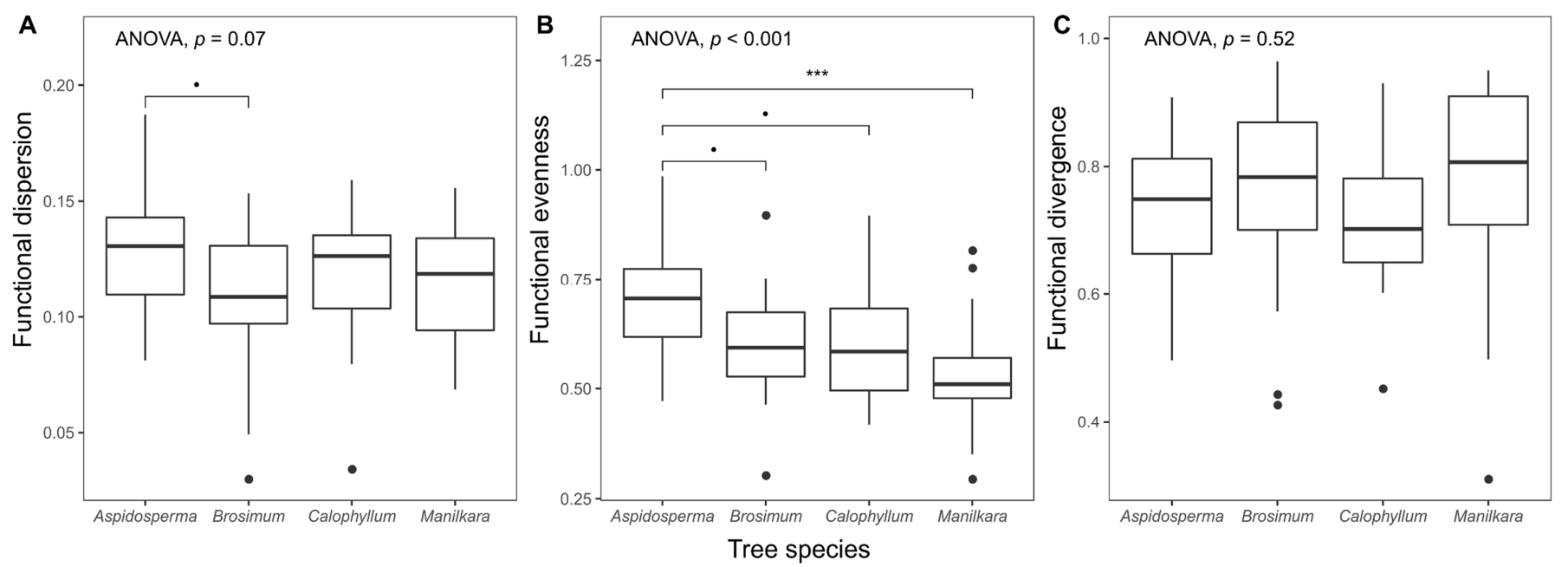

Figure 5. Functional diversity indices of crown epiphyte assemblages on focal host tree species. Boxplots show median, interquartile range and largest values within 1.5 times interquartile range below and above the 25th and 75th percentiles, respectively. Solid circles are outliers. Also given are $p$-values from analysis of variance, as well as the results of Tukey's post-hoc tests (Significance codes: “***” $p<0.001$; “•": $0.05 \leq p \leq 0.1$ ).

\section{Discussion}

\subsection{Trait Covariation}

The bivariate relationships between leaf morphological and chemical traits of the epiphytes of this lowland forest were generally consistent with those found in non-epiphytic plants, e.g., in SLA, SRL, and leaf and root nutrient contents [32,50,52]. However, for other traits there were noteworthy deviations. While the positive relationship between $\mathrm{H}_{\max }$ and LA $_{\max }$ was in accordance with the findings by Díaz et al. [52], the negatively correlation of $\mathrm{H}_{\max }$ with SLA was not: Díaz et al. [52] found no correlation between $\mathrm{H}_{\max }$ and SLA for herbaceous terrestrials. Similarly, a positive correlation of SLA and SD [80] could not be found in these vascular epiphytes. Díaz et al. [52] observed, expected from whole plant trait coordination [53], a negative correlation of SSD with SLA for herbaceous species, again at odds with our dataset. This discrepancy may be attributable to the fact that the requirements for stem morphology demanded by the main stem functions (water transport and mechanical support) are less uniform in epiphytes. Many epiphyte species have either very short and reduced stems (e.g., bromeliads, cespitose orchids) or a rhizome that grows appressed to the substrate. Moreover, for many epiphyte species (especially orchids with pseudobulbs) storage may be the dominant function. As a relevant trait in forestry, SSD data are widely available for trees but not for herbaceous species [20]. To include this trait in their global assessment, Díaz et al. [52] estimated SSD of herbs from LDMC. However, in our dataset LDMC and SSD were only weakly correlated $(r=0.24)$, indicating that for epiphytes such estimates would be unreliable.

The strong, negative correlation between SRL and RD is consistent with findings of many other studies (e.g., [51,55]) because with constant RTD, SRL scales inversely with root diameter squared [50] According to a postulated root economics spectrum, SRL should be negatively correlated with RTD. This expectation was met in a study with herbs [50] but not in analyses based exclusively or primarily on woody species [51,55]. In our dataset, the two variables were positively correlated. Similarly, the observed negative correlation between RTD and RD parallels previous findings of Weemstra et al. [55] and Ma et al. [51], 
but not of Roumet et al. [50]. This suggests that in regard to root trait correlations vascular epiphytes resemble woody plants more than terrestrial herbs.

Given the large number of traits in the principal component analysis, it is remarkable that almost two thirds of the variation in the trait data was captured by only four dimensions. In the analysis of Díaz et al. [52] the first principal component was attributable to plant size and covarying traits while the second PC corresponded to the LES. In our PCA, these two dimensions also emerged as independent axes, but their relative importance was reversed (LES corresponded primarily to PC 1, while plant size was well represented by PC 3) - presumably because the range of plant sizes was much larger for their global dataset, including trees, than for our much smaller dataset on epiphytes that includes only herbaceous species of one forest. Root traits captured substantially more variation than plant size as indicated by their close correlation with PC 2. Kramer-Walter et al. [81] analyzed root, stem and leaf traits of tree seedlings via PCA. They found RTD to be highly correlated with the typical LES traits (SLA, LDMC), while SRL (and the negatively correlated RD) aligned along an orthogonal axis to these traits and was thus independent from RTD. Like their results, we found SLA, LDMC, and RTD and the strongly negatively correlated SRL and $\mathrm{RD}$ to be represented by different axes, but the axes were much less orthogonal.

The clustering of plant families in the ordination plots (Figure 3 and Figure S2C,D) suggests a phylogenetic signal in some studied traits. Particularly illustrative are Orchidaceae, which account for $44 \%$ of all taxa in our trait dataset-globally, they even account for c. $66 \%$ of all epiphyte species [82]. Orchids occupy a larger proportion of the ordination space than any other family but still clearly separate from most other families caused by their positioning along the RD/SRL axis due to their velamen radicum.

\subsection{The Relationship of Epiphyte Trait Patterns and Host Tree Species}

For the tree crown zone, our data yield strong evidence for trait matching between host tree and epiphyte species and, thus, species sorting exerted by species-specific environmental conditions on different tree species. Some of the observed CWM differences suggest that Brosimum has a more open crown than Aspidosperma and Calophyllum. Epiphytes on Brosimum with $C_{3}$ photosynthesis had higher $\delta^{13} C$ values (=higher intrinsic water use efficiency) and more succulent leaves (lower LDMC, higher $\mathrm{L}_{\text {th }}$ ). Moreover, there was also a higher incidence of CAM plants on Brosimum as compared to Manilkara. Einzmann et al. [16] also found more CAM species on drought-deciduous vs. evergreen tree species. Although all four tree species in our study are evergreen, Brosimum has a relatively open crown and the highest temperature maxima of the studied trees [47]. In turn, light intensity was lowest on Manilkara, consistent with the low incidence of CAM plants on this tree species in the present study.

Microclimatic differences are only one aspect of trait matching, other factors are, e.g., bark properties and nutrient availability. For example, in addition to varying microclimate, differences in $\delta^{13} \mathrm{C}$ and $\mathrm{L}_{\text {th }}$ between epiphytes on Brosimum, Aspidosperma, and Calophyllum could also be related to differences in bark water holding capacity, which should increase with bark rugosity. The observed differences regarding bark rugosity are partly congruent with differences in CWMs. In accordance with the trait patterns, Brosimum has a very smooth bark that will dry out quickly after being wetted, while the bark of Calophyllum has deep fissures that will withhold moisture for longer, and Manilkara has by far the roughest bark [47]. Epiphytes on Manilkara had, on average, higher stomatal density, and smaller stomata than those on Brosimum.

We cannot explain the observed tree-related differences in the CWMs of root morphological traits, but they may reflect differences in water and nutrient availability. Within our epiphyte assemblages, high RD values indicate a velamen radicum (Figure 5C), presumed to be advantageous for effective water (and nutrient) uptake in tree canopies [65]. Therefore, we expected that epiphyte assemblages on tree species that pose stronger challenges regarding water supply (with low bark water holding capacity or open crown) would host a larger proportion of individuals with such large diameter roots. According to observed 
patterns regarding epiphyte leaf traits on tree species and direct measurements of tree traits, we would thus expect the highest RD values on Brosimum. This expectation did not bear out: epiphytes in Brosimum had the lowest RD and highest SRL CWMs, while high RD were observed in Aspidosperma. Possibly, the hypothesized relationship between RD and canopy openness is simply not well justified-such a relationship was not found either for orchids along the vertical gradient in the forest [24].

Most CWMs of mass-based epiphyte leaf and root nutrient traits differed with tree species (exceptions were leaf $\mathrm{K}$ and $\mathrm{Mg}$ and root $\mathrm{Ca}$ ). These traits may directly reflect the nutrient availability of the substrate, e.g., be determined by bark and leaf nutrient leaching. Unfortunately, we have no information on nutrient availability in the studied tree species to assess this notion, but tree species composition has been shown to strongly affect nutrient fluxes in throughfall and stemflow in tropical forests $[83,84]$. Foliar $\delta^{15} \mathrm{~N}$ is generally positively correlated with both, LNC and N availability [85], but we found no treerelated differences in assemblages regarding this trait, possibly indicating that the pattern regarding LNC is not caused by differences in $\mathrm{N}$ availability. Tissue nutrient concentrations are not merely a function of nutrient supply as they also covary with morphological traits of an organ. For example, mass-based leaf $\mathrm{N}$ and $\mathrm{P}$ were generally strongly correlated with SLA [32]. In the case of roots, there was a relatively tight correlation between RD and root $\mathrm{K}$ and $\mathrm{Mg}$ concentrations ( $\mathrm{r}=0.58$ and 0.51 , respectively). This could explain the high CWMs of RKC and RMgC on Aspidosperma, which hosted the assemblages with the highest RD.

The measurements of the SPAD chlorophyll meter correlate with chlorophyll concentration per area, (e.g., in [86]). Given that Petter et al. [3], using the same device, found only a weak (positive) relationship for LChl along the vertical gradient in the forest and LChl of sun and shade leaves are generally comparable [87], we expected at most a weak difference among tree species. In contrast, Brosimum had significantly lower CWMs of LChl than the other tree species. However, we note a bias because the SPAD device can be used only for leaves with $<1.2 \mathrm{~mm}$ thickness and the most succulent leaves were excluded.

Besides trait averages of crown assemblages, functional diversity was also affected by tree species, albeit weakly. Paralleling the patterns found for CWMs, the strongest difference in functional diversity was observed between Aspidosperma (highest) and Brosimum (lowest). The trait spread of epiphyte assemblages on Aspidosperma was, on average, higher than on Brosimum (indicated by the functional dispersion index), where assemblages were less dominated by certain trait values than on the other tree species (indicated by functional evenness). This suggests trait convergence on Brosimum (more adverse conditions for epiphytes impose a stronger environmental filter) and a greater diversity of growing conditions or more beneficial conditions on Aspidosperma. The first notion is congruent with the finding that Brosimum has the lowest epiphyte accumulation rate of the four study species after accounting for tree growth rates [47]. However, in contrast to this conclusion, the previous study suggested also relatively adverse conditions on Aspidosperma, as this species generally had a lower epiphyte load compared to the other study species and ranked lower than Calophyllum and Manilkara in terms of epiphyte accumulation with time.

The expectation that host specificity depends on the vertical position on a tree was clearly supported. In contrast to crown assemblages, there were no differences in FD, and only one out of 28 traits showed differences regarding CWMs for trunk assemblages. This suggests that differences in crown architecture among tree species resulting in microclimatic differences in the upper part of the trees are more important for host specificity than differences in bark structure, which should be stronger in the lower part of a tree. Moreover, this finding supports the suggestion of Mendieta-Leiva and Zotz [48]: epiphyte host specificity should be analyzed separately for the different tree zones-at least in tall lowland rainforests with strong microclimatic differences between upper canopy and understory. However, it should be noted that the absence of significant differences of epiphyte CWMs among tree species on the tree trunk coincides with much lower numbers of epiphytes in this zone. 
By calculating CWMs and FD indices based on epiphyte species trait averages, the present study considers only the part of the possible trait-environment relationships that is taxonomically constrained, as we calculate CWMs from average trait values per species, and thus ignore possible intraspecific adjustment of trait values along environmental gradients. For our research question (epiphyte host specificity), this approach is reasonable because specificity in species interactions can only result from differences at the species level. However, trait-environment relationships can also be caused by acclimation and sorting of genotypes causing intra-specific trait variation. For example, Einzmann et al. [16] found intraspecific differences for some combinations of the studied leaf traits and epiphyte species. When intra- and interspecific trait-environment relationships have the same direction [3], patterns as in the present study would only be reinforced by the inclusion of the intraspecific level. However, the assumption of an identical directionality does not always hold true as demonstrated by Kichenin et al. [88], who found several leaf traits (SLA, LNC and LPC) to respond with opposing directions at the inter- and intraspecific level along an elevational gradient. Therefore, future studies should also consider the intraspecific level.

Compared to previous trait studies with vascular epiphytes, the present study included an unprecedented large number of trait types. However, traits related to dispersal and seed adherence, which could be very important in the context of epiphyte host specificity, were not assessed. For example, diaspore size as well as structures that aid in the attachment to the bark may cause distributional biases among tree species with different bark types. It would certainly be worthwhile for future studies to assess the role of these traits.

\section{Conclusions}

Our study found intriguing indications for differences between epiphytes and terrestrial plants regarding trait covariation. However, even though our dataset comprises almost 100 epiphyte species, it is still small compared to the large datasets on which trait covariation analyses are often based. Future studies with larger datasets will show whether our results really identify general functional adaptations needed to thrive in the aerial habitat.

We found evidence for habitat-quality differences between host trees leading to trait filtering of epiphytes. In the tree crown, more than two thirds of the studied CWM traits of epiphyte assemblages differed significantly among the focal tree species. This finding is an important piece of the puzzle, as it gives us more certainty that epiphyte host specificity exists in high diversity systems such as the studied forest, although we were not able to fully explain the observed trait patterns with the available information regarding trait differences of the focal tree species. However, future studies with a stronger simultaneous focus on important tree traits should allow a full functional understanding of epiphyte host specificity.

Supplementary Materials: The following are available online at https://www.mdpi.com/1424-281 8/13/2/97/s1, Figure S1: Correlation matrix for 26 traits, Figure S2: Principal component analysis of functional traits (excluding stomatal and root traits) of the epiphytic community at study site, Figure S3: CWMs of different traits on stems of focal tree species, Figure S4: CWMs of different traits in crowns of focal tree species. Table S1: Principal component analysis of functional traits, Table S2: Principal component analysis of CWMs functional traits, Table S3: Results of ANOVAs and pairwise comparisons of CWMs of traits on tree species for crown and trunk assemblages, File S1: References for trait-trait and trait-environment relationships depicted in Figures 1 and 2.

Author Contributions: Conceptualization, K.W. and G.Z.; Methodology, K.W.; Formal analysis, K.W.; Resources, K.W., G.Z., and W.W.; Data Curation, K.W.; Writing-original draft preparation, K.W.; Writing - review and editing, K.W., G.Z., and W.W.; Project administration, K.W.; Funding acquisition, K.W. All authors have read and agreed to the published version of the manuscript.

Funding: This work was funded by the Deutsche Forschungsgemeinschaft (WA 3936/1-1). 
Institutional Review Board Statement: Not applicable.

Informed Consent Statement: Not applicable.

Data Availability Statement: Upon publication, data will be made publicly available in the TRY database.

Acknowledgments: This study would not have been possible without the dedicated help of many. Chrissi Göbel, Florian Masche, Paula Morales, Lilisbeth Rodríguez, Sebastian Schäfer, and Tizian Weichgrebe helped with carrying out the epiphyte census and sample processing in Panama. Samples were also processed and analysed in Oldenburg by Karoline Hots, Valerie-Manon Eppert, Niels Kappert, Katharina Lindefjeld, Norbert Wagner, and Malte Weber. Michael Kleyer (Oldenburg) kindly let us use his WinRhizo software for root analyses. We thank the Smithsonian Tropical Research Institute (STRI) for providing the necessary lab and field infrastructure and the Republic of Panama for making its natural resources available (research permits: SE/P-32-16 and SC/P-3-18).

Conflicts of Interest: The authors declare no conflict of interest. The funders had no role in the design of the study; in the collection, analyses, or interpretation of data; in the writing of the manuscript, or in the decision to publish the results.

\section{References}

1. Zotz, G. Plants on Plants-The Biology of Vascular Epiphytes; Springer International Publishing: Cham, Switzerland, 2016. [CrossRef]

2. Janzen, T.; Zotz, G.; Etienne, R.S. Community structure of vascular epiphytes: A neutral perspective. Oikos 2020, $129,853-867$. [CrossRef]

3. Petter, G.; Wagner, K.; Wanek, W.; Sánchez Delgado, E.J.; Zotz, G.; Cabral, J.S.; Kreft, H. Functional leaf traits of vascular epiphytes: Vertical trends within the forest, intra- and interspecific trait variability, and taxonomic signals. Funct. Ecol. 2016, 30, 188-198. [CrossRef]

4. Zotz, G. Johansson revisited: The spatial structure of epiphyte assemblages. J. Veg. Sci. 2007, 18, 123-130. [CrossRef]

5. Krömer, T.; Kessler, M.; Gradstein, S.R. Vertical stratification of vascular epiphytes in submontane and montane forest of the Bolivian Andes: The importance of the understory. Plant Ecol. 2007, 189, 261-278. [CrossRef]

6. Zotz, G. How prevalent is crassulacean acid metabolism among vascular epiphytes? Oecologia 2004, 138, 184-192. [CrossRef] [PubMed]

7. Wagner, K.; Mendieta-Leiva, G.; Zotz, G. Host specificity in vascular epiphytes: A review of methodology, empirical evidence and potential mechanisms. AoB Plants 2015, 7, plu092. [CrossRef]

8. Chaves, C.J.N.; Dyonisio, J.C.; Rossatto, D.R. Host trait combinations drive abundance and canopy distribution of atmospheric bromeliad assemblages. AoB Plants 2016, 8, plw010. [CrossRef]

9. Laube, S.; Zotz, G. Neither host-specific nor random: Vascular epiphytes on three tree species in a Panamanian lowland forest. Ann. Bot. 2006, 97, 1103-1114. [CrossRef]

10. Vergara-Torres, C.A.; Pacheco-Alvarez, M.C.; Flores-Palacios, A. Host preference and host limitation of vascular epiphytes in a tropical dry forest of central Mexico. J. Trop. Ecol. 2010, 26, 563-570. [CrossRef]

11. Schleuning, M.; Fründ, J.; García, D. Predicting ecosystem functions from biodiversity and mutualistic networks: An extension of trait-based concepts to plant-animal interactions. Ecography 2015, 38, 380-392. [CrossRef]

12. Callaway, R.M.; Reinhart, K.O.; Moore, G.W.; Moore, D.J.M.; Pennings, S.C. Epiphyte host preferences and host traits: Mechanisms for species-specific interactions. Oecologia 2002, 132, 221-230. [CrossRef]

13. Mehltreter, K.; Flores-Palacios, A.; García-Franco, J.G. Host preferences of low-trunk vascular epiphytes in a cloud forest of Veracruz, Mexico. J. Trop. Ecol. 2005, 21, 651-660. [CrossRef]

14. Garth, R.E. The ecology of spanish moss (Tillandsia usneoides): Its growth and distribution. Ecology 1964, 45, 470-481. [CrossRef]

15. Cardelús, C.L.; Chazdon, R.L. Inner-crown microenvironments of two emergent tree species in a lowland wet forest. Biotropica 2005, 37, 238-244. [CrossRef]

16. Einzmann, H.J.R.; Beyschlag, J.; Hofhansl, F.; Wanek, W.; Zotz, G. Host tree phenology affects vascular epiphytes at the physiological, demographic and community level. AoB Plants 2015, 7, plu73. [CrossRef]

17. Sarmento Cabral, J.; Petter, G.; Mendieta-Leiva, G.; Wagner, K.; Zotz, G.; Kreft, H. Branchfall as a demographic filter for epiphyte communities: Lessons from forest floor-based sampling. PLoS ONE 2015, 10, e0128019. [CrossRef]

18. Schlesinger, W.J.; Marks, P.L. Mineral cycling and the niche of Spanish moss, Tillandsia usneoides L. Am. J. Bot. 1977, 64, 1254-1262. [CrossRef]

19. Martin, C.E.; Lin, T.-C.; Hsu, C.-C.; Lin, S.-H. No effect of host tree species on the physiology of the epiphytic orchid Bulbophyllum japonicum in a subtropical rainforest in Northeastern Taiwan. Taiwan J. For. Sci. 2007, 22, 241-251.

20. Kattge, J.; Bönisch, G.; Díaz, S.; Lavorel, S.; Prentice, I.C.; Leadley, P.; Tautenhahn, S.; Werner, G.D.A.; Aakala, T.; Abedi, M.; et al. TRY plant trait database-Enhanced coverage and open access. Glob. Chang. Biol. 2020, 26, 119-188. [CrossRef]

21. Violle, C.; Navas, M.-L.; Vile, D.; Kazakou, E.; Fortunel, C.; Hummel, I.; Garnier, E. Let the concept of trait be functional! Oikos 2007, 116, 882-892. [CrossRef] 
22. Schellenberger Costa, D.; Zotz, G.; Hemp, A.; Kleyer, M. Trait patterns of epiphytes compared to other plant life forms along a tropical elevation gradient. Funct. Ecol. 2018, 32, 2073-2084. [CrossRef]

23. Agudelo, C.M.; Benavides, A.M.; Taylor, T.; Feeley, K.J.; Duque, A. Functional composition of epiphyte communities in the Colombian Andes. Ecology 2019, 100, e02858. [CrossRef] [PubMed]

24. Einzmann, H.J.R.; Schickenberg, N.; Zotz, G. Variation in root morphology of epiphytic orchids along small-scale and large-scale moisture gradients. Acta Bot. Bras. 2020, 34, 66-73. [CrossRef]

25. Cach-Pérez, M.J.; Andrade, J.L.; Cetzal-Ix, W.; Reyes-García, C. Environmental influence on the inter- and intraspecific variation in the density and morphology of stomata and trichomes of epiphytic bromeliads of the Yucatan Peninsula. Bot. J. Linn. Soc. 2016, 181, 441-458. [CrossRef]

26. Susan-Tepetlan, T.M.; Velázquez-Rosas, N.; Krömer, T. Cambios en las características funcionales de epífitas vasculares de bosque mesófilo de montana y vegetación secundaria en la región central de Veracruz, México. Bot. Sci. 2015, 93, 1-11. [CrossRef]

27. Paula Oliveira, R.; Zotz, G.; Wanek, W.; Franco, A.C. Leaf trait co-variation and trade-offs in gallery forest C3 and CAM epiphytes. Biotropica 2021, in press. [CrossRef]

28. Smith, W.K.; Bell, D.T.; Shepherd, K.A. Associations between leaf structure, orientation, and sunlight exposure in five Western Australian communities. Am. J. Bot. 1998, 85, 56-63. [CrossRef]

29. Niinemets, Ü. Global-scale climatic controls of leaf dry mass per area, density, and thickness in trees and shrubs. Ecology 2001, 82, 453-469. [CrossRef]

30. Cornwell, W.K.; Ackerly, D.D. Community assembly and shifts in plant trait distributions across an environmental gradient in coastal California. Ecol. Monogr. 2009, 79, 109-126. [CrossRef]

31. Peppe, D.J.; Royer, D.L.; Cariglino, B.; Oliver, S.Y.; Newman, S.; Leight, E.; Enikolopov, G.; Fernandez-Burgos, M.; Herrera, F.; Adams, J.M.; et al. Sensitivity of leaf size and shape to climate: Global patterns and paleoclimatic applications. New Phytol. 2011, 190, 724-739. [CrossRef] [PubMed]

32. Wright, I.J.; Reich, P.B.; Westoby, M.; Ackerly, D.D.; Baruch, Z.; Bongers, F.; Cavender-Bares, J.; Chapin, T.; Cornelissen, J.H.C.; Diemer, M.; et al. The worldwide leaf economics spectrum. Nature 2004, 428, 821-827. [CrossRef]

33. Zotz, G.; Schickenberg, N.; Albach, D. The velamen radicum is common among terrestrial monocotyledons. Ann. Bot. 2017, 120, 625-632. [CrossRef]

34. Sanford, W.W.; Adanlawo, F.L.S.; Adanlawo, I. Velamen and exodermis characters of West African epiphytic orchids in relation to taxonomic grouping and habitat tolerance. Bot. J. Linn. Soc. 1973, 66, 307-321. [CrossRef]

35. Franks, P.J.; Beerling, D.J. Maximum leaf conductance driven by $\mathrm{CO}_{2}$ effects on stomatal size and density over geologic time. Proc. Natl. Acad. Sci. USA 2009, 106, 10343-10347. [CrossRef] [PubMed]

36. Hietz, P.; Briones, O. Correlation between water relations and within-canopy distribution of epiphytic ferns in a Mexican cloud forest. Oecologia 1998, 114, 305-316. [CrossRef] [PubMed]

37. Xu, Z.; Zhou, G. Responses of leaf stomatal density to water status and its relationship with photosynthesis in a grass. J. Exp. Bot. 2008, 59, 3317-3325. [CrossRef] [PubMed]

38. Körner, C.; Scheel, J.A.; Bauer, H. Maximum leaf diffusive conductance in vascular plants. Photosynthetica 1979, 13, 45-82.

39. Murray, M.; Soh, W.K.; Yiotis, C.; Batke, S.; Parnell, A.C.; Spicer, R.A.; Lawson, T.; Caballero, R.; Wright, I.J.; Purcell, C.; et al. Convergence in maximum stomatal conductance of $\mathrm{C} 3$ woody angiosperms in natural ecosystems across bioclimatic zones. Front. Plant Sci. 2019, 10, 558. [CrossRef] [PubMed]

40. Bruelheide, H.; Dengler, J.; Purschke, O.; Lenoir, J.; Jiménez-Alfaro, B.; Hennekens, S.M.; Botta-Dukát, Z.; Chytrý, M.; Field, R.; Jansen, F.; et al. Global trait-environment relationships of plant communities. Nat. Ecol. Evol. 2018, 2, 1906-1917. [CrossRef]

41. Marks, C.; Lechowicz, M. Alternative designs and the evolution of functional diversity. Am. Nat. 2006, 167, 55-66. [CrossRef] [PubMed]

42. Jager, M.M.; Richardson, S.J.; Bellingham, P.J.; Clearwater, M.J.; Laughlin, D.C. Soil fertility induces coordinated responses of multiple independent functional traits. J. Ecol. 2015, 103, 374-385. [CrossRef]

43. Schellenberger Costa, D.; Gerschlauer, F.; Pabst, H.; Kühnel, A.; Huwe, B.; Kiese, R.; Kuzyakov, Y.; Kleyer, M. Communityweighted means and functional dispersion of plant functional traits along environmental gradients on Mount Kilimanjaro. J. Veg. Sci. 2017, 28, 684-695. [CrossRef]

44. Grime, J.P. Trait convergence and trait divergence in herbaceous plant communities: Mechanisms and consequences. J. Veg. Sci. 2006, 17, 255-260. [CrossRef]

45. Laliberté, E.; Norton, D.A.; Scott, D. Contrasting effects of productivity and disturbance on plant functional diversity at local and metacommunity scales. J. Veg. Sci. 2013, 24, 834-842. [CrossRef]

46. Johansson, D. Ecology of vascular epiphytes in West African rain forests. Acta Phytogeogr. Suec. 1974, 59, 1-129.

47. Wagner, K.; Zotz, G. Including dynamics in the equation: Tree growth rates and host specificity of vascular epiphytes. J. Ecol. 2020, 108, 761-773. [CrossRef]

48. Mendieta-Leiva, G.; Zotz, G. A conceptual framework for the analysis of vascular epiphyte assemblages. Perspect. Plant Ecol. Evol. Syst. 2015, 17, 510-521. [CrossRef]

49. Chave, J.; Coomes, D.; Jansen, S.; Lewis, S.L.; Swenson, N.G.; Zanne, A.E. Towards a worldwide wood economics spectrum. Ecol. Lett. 2009, 12, 351-366. [CrossRef] 
50. Roumet, C.; Birouste, M.; Picon-Cochard, C.; Ghestem, M.; Osman, N.; Vrignon-Brenas, S.; Cao, K.-F.; Stokes, A. Root structurefunction relationships in 74 species: Evidence of a root economics spectrum related to carbon economy. New Phytol. 2016, 210, 815-826. [CrossRef]

51. Ma, Z.; Guo, D.; Xu, X.; Lu, M.; Bardgett, R.D.; Eissenstat, D.M.; McCormack, M.L.; Hedin, L.O. Evolutionary history resolves global organization of root functional traits. Nature 2018, 555, 94. [CrossRef]

52. Díaz, S.; Kattge, J.; Cornelissen, J.H.C.; Wright, I.J.; Lavorel, S.; Dray, S.; Reu, B.; Kleyer, M.; Wirth, C.; Colin Prentice, I.; et al. The global spectrum of plant form and function. Nature 2016, 529, 167-171. [CrossRef] [PubMed]

53. Reich, P.B. The world-wide 'fast-slow' plant economics spectrum: A traits manifesto. J. Ecol. 2014, 102, 275-301. [CrossRef]

54. Westoby, M.; Wright, I.J. Land-plant ecology on the basis of functional traits. Trends Ecol. Evol. 2006, 21, 261-268. [CrossRef]

55. Weemstra, M.; Mommer, L.; Visser, E.J.W.; Ruijven, J.; Kuyper, T.W.; Mohren, G.M.J.; Sterck, F.J. Towards a multidimensional root trait framework: A tree root review. New Phytol. 2016, 211, 1159-1169. [CrossRef]

56. Valverde-Barrantes, O.J.; Smemo, K.A.; Blackwood, C.B. Fine root morphology is phylogenetically structured, but nitrogen is related to the plant economics spectrum in temperate trees. Funct. Ecol. 2015, 29, 796-807. [CrossRef]

57. Westoby, M.; Falster, D.S.; Moles, A.T.; Vesk, P.A.; Wright, I.J. Plant ecological strategies: Some leading dimensions of variation between species. Annu. Rev. Ecol. Syst. 2002, 33, 125-159. [CrossRef]

58. Paton, S. Meteorological Summary for the San Lorenzo/Fort Sherman Canopy Crane; Smithsonian Tropical Research Institute: Panama City, Panama, 2017; Available online: https://biogeodb.stri.si.edu/physical_monitoring/ (accessed on 1 December 2020).

59. Wright, S.J.; Horlyck, V.; Basset, Y.; Barrios, H.; Bethancourt, A.; Bohlman, S.A.; Gilbert, G.S.; Goldstein, G.; Graham, E.A.; Kitajima, K.; et al. Tropical canopy biology program, Republic of Panama. In Studying Forest Canopies from Above: The International Canopy Crane Network; Basset, Y., Horlyck, V., Wright, S.J., Eds.; Smithsonian Tropical Research Institute: Ancon, Panama; United Nations Environmental Programme: New York, NY, USA, 2003; pp. 137-155.

60. Zotz, G.; Schultz, S. The vascular epiphytes of a lowland forest in Panama-species composition and spatial structure. Plant Ecol. 2008, 195, 131-141. [CrossRef]

61. Condit, R. Tropical Forest Census Plots; Springer: Berlin, Germany, 1998.

62. Pérez-Harguindeguy, N.; Díaz, S.; Garnier, E.; Lavorel, S.; Poorter, H.; Jaureguiberry, P.; Bret-Harte, M.S.; Cornwell, W.K.; Craine, J.M.; Gurvich, D.E.; et al. New handbook for standardised measurement of plant functional traits worldwide. Aust. J. Bot. 2013, 61, 167-234. [CrossRef]

63. Schindelin, J.; Arganda-Carreras, I.; Frise, E.; Kaynig, V.; Longair, M.; Pietzsch, T.; Preibisch, S.; Rueden, C.; Saalfeld, S.; Schmid, B.; et al. Fiji: An open-source platform for biological-image analysis. Nat. Methods 2012, 9, 676-682. [CrossRef]

64. James, S.A.; Bell, D.T. Leaf morphological and anatomical characteristics of heteroblastic Eucalyptus globulus ssp. globulus (Myrtaceae). Aust. J. Bot. 2001, 49, 259-269. [CrossRef]

65. Zotz, G.; Winkler, U. Aerial roots of epiphytic orchids: The velamen radicum and its role in water and nutrient uptake. Oecologia 2013, 171, 733-741. [CrossRef] [PubMed]

66. Göbel, C.Y.; Schlumpberger, B.O.; Zotz, G. What Is a pseudobulb? Towards a quantitative definition. Int. J. Plant Sci. 2020, 181, 686-696. [CrossRef]

67. Luh Huang, C.Y.; Schulte, E.E. Digestion of plant tissue for analysis by ICP emission spectroscopy. Commun. Soil Sci. Plant Anal. 1985, 16, 943-958. [CrossRef]

68. Murphy, J.; Riley, J.P. A single-solution method for the determination of soluble phosphate in sea water. J. Mar. Biol. Assoc. UK 1958, 37, 9-14. [CrossRef]

69. R_Core_Team R: A Language and Environment for Statistical Computing; R Foundation for Statistical Computing: Vienna, Austria, 2018.

70. Wickham, H. ggplot2: Elegant Graphics for Data Analysis; Springer: New York, NY, USA, 2016.

71. Wei, T.; Simko, V. R package corrplot: Visualization of a Correlation Matrix. Statistician 2017, 56, e24.

72. Le, S.; Josse, J.; Husson, F. FactoMineR: An R package for multivariate analysis. J. Stat. Softw. 2008, 25, 1-18. [CrossRef]

73. Kassambra, A.; Mundt, F. Factoextra: Extract and Visualize the Results of Multivariate Data Analyses, R Package Version 1.0.6. Available online: https://rpkgs.datanovia.com/factoextra/index.html (accessed on 7 November 2020).

74. Lavorel, S.; Grigulis, K.; McIntyre, S.; Williams, N.S.G.; Garden, D.; Dorrough, J.; Berman, S.; Quetier, F.; Thebault, A.; Bonis, A. Assessing functional diversity in the field-Methodology matters! Funct. Ecol. 2008, 22, 134-147. [CrossRef]

75. Laliberté, E.; Legendre, P. A distance-based framework for measuring functional diversity from multiple traits. Ecology 2010, 91, 299-305. [CrossRef]

76. Laliberté, E.; Legendre, P.; Shipley, B. FD: Measuring Functional Diversity from Multiple Traits, and Other Tools for Functional Ecology. Available online: https:/ /rdrr.io/cran/FD/ (accessed on 1 December 2020).

77. Villéger, S.; Mason, N.W.H.; Mouillot, D. New multidimensional functional diversity indices for a multifaceted framework in functional ecology. Ecology 2008, 89, 2290-2301. [CrossRef] [PubMed]

78. Herberich, E.; Sikorski, J.; Hothorn, T. A robust procedure for comparing multiple means under heteroscedasticity in unbalanced designs. PLoS ONE 2010, 5, e9788. [CrossRef] [PubMed]

79. Hothorn, T.; Bretz, F.; Westfall, P. Simultaneous inference in general parametric models. Biom. J. 2008, 50, 346-363. [CrossRef] [PubMed] 
80. Loranger, J.; Shipley, B. Interspecific covariation between stomatal density and other functional leaf traits in a local flora. Botany 2010, 88, 30-38. [CrossRef]

81. Kramer-Walter, K.R.; Bellingham, P.J.; Millar, T.R.; Smissen, R.D.; Richardson, S.J.; Laughlin, D.C. Root traits are multidimensional: Specific root length is independent from root tissue density and the plant economic spectrum. J. Ecol. 2016, 104, 1299-1310. [CrossRef]

82. Zotz, G. The systematic distribution of vascular epiphytes-A critical update. Bot. J. Linn. Soc. 2013, 171, 453-481. [CrossRef]

83. Hofhansl, F.; Wanek, W.; Drage, S.; Huber, W.; Weissenhofer, A.; Richter, A. Topography strongly affects atmospheric deposition and canopy exchange processes in different types of wet lowland rainforest, Southwest Costa Rica. Biogeochemistry 2011, 106, 371-396. [CrossRef]

84. Hofhansl, F.; Wanek, W.; Drage, S.; Huber, W.; Weissenhofer, A.; Richter, A. Controls of hydrochemical fluxes via stemflow in tropical lowland rainforests: Effects of meteorology and vegetation characteristics. J. Hydrol. 2012, 452-453, 247-258. [CrossRef]

85. Craine, J.M.; Elmore, A.J.; Aidar, M.P.M.; Bustamante, M.; Dawson, T.E.; Hobbie, E.A.; Kahmen, A.; Mack, M.C.; McLauchlan, K.K.; Michelsen, A.; et al. Global patterns of foliar nitrogen isotopes and their relationships with climate, mycorrhizal fungi, foliar nutrient concentrations, and nitrogen availability. New Phytol. 2009, 183, 980-992. [CrossRef]

86. Coste, S.; Baraloto, C.; Leroy, C.; Marcon, E.; Renaud, A.; Richardson, A.D.; Roggy, J.C.; Schimann, H.; Uddling, J.; Herault, B. Assessing foliar chlorophyll contents with the SPAD-502 chlorophyll meter: A calibration test with thirteen tree species of tropical rainforest in French Guiana. Ann. For. Sci. 2010, 67, 607. [CrossRef]

87. Lambers, H.; Chapin, F.S., III; Pons, T.L. Plant Physiological Ecology, 2nd ed.; Springer: New York, NY, USA, 2008 ; p. 540.

88. Kichenin, E.; Wardle, D.A.; Peltzer, D.A.; Morse, C.W.; Freschet, G.T. Contrasting effects of plant inter- and intraspecific variation on community-level trait measures along an environmental gradient. Funct. Ecol. 2013, 27, 1254-1261. [CrossRef] 